\title{
MODEL THINK TALK WRITE BERBANTUAN MEDIA MONOMAT MENINGKATKAN KEMAMPUAN KOMUNIKASI MATEMATIKA SISWA SEKOLAH DASAR
}

\author{
Dylla Akny Noviarny ${ }^{1 \bowtie}$, Murtono $^{2}$, dan Himmatul Ulya ${ }^{3}$ \\ ${ }^{1}$ SD 2 Prambatan Lor Kudus, Universitas Muria Kudus, \\ ${ }^{2}$ Prodi Pendidikan Guru Sekolah Dasar, Universitas Muria Kudus \\ ${ }^{3}$ Prodi Pendidikan Matematika, Universitas Muria Kudus
}

\begin{tabular}{l}
\hline Info Artikel \\
\hline Sejarah Artikel: \\
Diterima 24 Feb 2018 \\
Direvisi 20 Mar 2018 \\
Disetujui 20 Apr 2018 \\
\hline \\
Keywords: Mathematical \\
Communication Ability, \\
Monomat, Think Talk \\
Write
\end{tabular}

\begin{abstract}
This research aims to: 1) improve teacher's skill in learning mathematics with Think Talk Write model, 2) to improve students' learning activity in mathematics learning with Think Talk Write (TTW) model, and 3) to improve students' mathematics communication abilittyin the fifth grade SD 1 Wergu Kulon with model TTW media-aided Mathematics Monopoly (Monomat) on twodimentional figure and three dimentional figure material. This research uses classroom action research method. The instruments used in this research are test type and non test. Data analysis is done quantitatively and qualitatively. Quantitative analysis is used to calculate classical mastery, grade averages, and average per mathematical communication ability indicator of students. Qualitative analysis uses rating scale. The results concluded that students' mathematical communication ability can be improved by using Think Talk Write model with monomat media. Students can think, speak, and write that lead to developing ideas or mathematical ideas so that students' math communication skills can evolve using Think Talk Write models.
\end{abstract}

Paper type:

Research paper

\begin{abstract}
Abstrak
Penelitian ini bertujuan untuk: 1) meningkatkan keterampilan guru dalam pembelajaran matematika dengan model Think Talk Write, 2) meningkatkan aktivitas belajar siswa dalam pembelajaran matematika dengan model Think Talk Write, dan 3) meningkatkan kemampuan komunikasi matematika siswa kelas V SD 1 Wergu Kulon dengan model Think Talk Write berbantuan media Monomat pada materi bangun datar dan bangun ruang. Penelitian ini menggunakan metode penelitian tindakan kelas. Instrumen yang digunakan dalam penelitian ini adalah jenis tes dan non tes. Analisis data dilakukan secara kuantitatif dan kualitatif. Analisis kuantitatif digunakan untuk mengitung ketuntasan klasikal, rata-rata kelas, dan rata-rata per indikator kemampuan komunikasi matematika siswa. Analisis kualitatif menggunakan rating scale. Hasil penelitian menyimpulkan bahwa kemampuan komunikasi matematika siswa dapat meningkat dengan menggunakan model pembelajaran Think Talk Write berbantuan media Monomat. Siswa dapat berpikir, berbicara, dan menulis yang mengarah pada mengembangkan ide atau gagasan matematika sehingga kemampuan komunikasi matematika siswa dapat berkembang dengan menggunakan model Think Talk Write.
\end{abstract}

(C) 2018 Universitas Muria Kudus

\footnotetext{
$\triangle$ Alamat korespondensi:

Program Studi Pendidikan Matematika, Universitas Muria Kudus

Kampus UMK Gondangmanis, Bae Kudus Gd. L lantai 1 Ruang 2 PO BOX 53 Kudus

Tlp. (0291) 438229 Fax. (0291) 437198

E-mail: dylla.akny14@gmail.com
} 


\section{PENDAHULUAN}

Pendidikan dasar yang dimulai dari Sekolah Dasar (SD) mengembangkan berbagai ilmu pengetahuan melalui beberapa mata pelajaran seperti: Bahasa Indonesia, Ilmu Pengetahuan Sosial, Ilmu Pengetahuan Alam, dan Matematika. Menurut Badan Satuan Nasional Pendidikan yang mengacu pada Peraturan Menteri Pendidikan Nasional (Permendiknas) Nomor 22 Tahun 2006, menyebutkan bahwa matematika merupakan ilmu universal yang mendasari perkembangan teknologi modern yang mempunyai peran penting dalam berbagai disiplin dan memajukan daya pikir manusia (BSNP:2006). Tujuan pembelajaran matematika yang tercantum di dalam kurikulum standar isi untuk satuan pendidikan dasar dan menengah (BSNP, 2006) diantaranya: (1) memecahkan masalah yang meliputi kemampuan memahami masalah, merancang model matematika, menyelesaikan model dan menafsirkan solusi yang diperoleh, dan (2) mengomunikasikan gagasan dengan simbol, tabel, diagram, atau media lain untuk memperjelas keadaan. Adanya tujuan tersebut mengharuskan agar kemampuan komunikasi matematika siswa penting untuk ditingkatkan.

Rendahnya kemampuan komunikasi matematika kelas $\mathrm{V} \quad \mathrm{SD} \quad 1$ Wergu Kulon ditunjukkan pada hasil pre-tes dengan perolehan 4 dari 29 siswa yang tuntas KKM dengan batas kriteria ketuntasan minimalnya yaitu 65 , atau sekitar $13,79 \%$ siswa yang tuntas dan $86,20 \%$ siswa tidak tuntas. Nilai rata-rata kelas kemampuan komunikasi matematika hanya mendapatkan nilai 33,96 dengan kriteria kurang.

Apabila dilihat dari nilai rata-rata kelas tiap indikator kemampuan komunikasi matematika pada indikator menghubungkan gambar menjadi ide matematika diperoleh hasil sebesar 45,68 dengan kriteria kurang. Nilai ratarata pada indikator menjelaskan/mendeskripsikan ide matematika menjadi gambar yaitu 42,11 dengan kriteria kurang. Pada indikator melakukan diskusi/menulis matematika, nilai rata-ratanya yaitu 46,55 dengan kriteria kurang. Sebesar 22,98 dengan kriteria sangat kurang diperoleh dari indikator membuat pertanyaan matematika yang sesuai dengan masalah, dan indikator membuat kesimpulan matematika diperoleh nilai rata-rata sebesar 24,59 dengan kriteria sangat kurang. Data dari nilai pre-tes tersebut menunjukkan rendahnya kemampuan komunikasi matematika siswa yang diukur dalam soal tes kemampuan komunikasi matematika.

Berdasarkan hasil wawancara dan pre-tes, penyebab timbulnya rendahnya komunikasi matematika siswa kelas V SD 1 Wergu Kulon yaitu: (1) guru lebih sering menyuruh siswa untuk maju mengerjakan soal di papan tulis dengan tidak 6 diimbangi dengan menyampaikan pendapat/ide/gagasan/jawaban secara langsung; (2) tidak adanya media yang memudahkan siswa dalam meningkatkan kemampuan komunikasi matematika; (3) kurangnya rasa percaya diri dan mental siswa yang merasa malu atau takut ketika diminta untuk menyampaikan ide-ide matematikanya; dan (4) pembelajaran matematikanya masih menggunakan metode konvensional sehingga komunikasi siswa masih terbatas karena guru menyampaikan materi seperti cara ceramah. Berdasarkan permasalahan tersebut, dikhawatirkan kemampuan komunikasi matematika siswa tidak dapat berkembang sehingga dalam menyampaikan ide, gagasan, membaca grafik, istilah, dan notasi matematika mengalami keterbatasan. Dengan pembelajaran matematika yang masih konvensional, komunikasi (lisan) siswa masih sangat terbatas, siswa hanya menjawab pertanyaan guru dengan jawaban-jawaban yang pendek.

Guna meningkatkan kemampuan komunikasi matematika siswa diperlukan suatu model pembelajaran yang memfasilitasi siswa untuk aktif menyampaikan ide-ide/gagasangagasan matematika. Salah satu model pembelajaran yang cocok adalah model Think Talk Write (TTW), yaitu model yang dapat membantu siswa untuk bisa berpikir, berbicara, dan menuliskan ide-ide matematika siswa sehingga dapat menumbuhkan kemampuan komunikasi matematika siswa. Hal tersebut selaras dengan pendapat Huda (2014:218) yang menyatakan bahwa model Think Talk Write mendorong siswa untuk bisa berpikir, berbicara, dan menuliskan suatu topik tertentu sehingga dapat mempengaruhi siswa mengembangkan ide atau gagasan matematikanya melalui lisan atau tulisan.

Langkah-langkah model TTW melibatkan proses kemampuan komunikasi matematika di setiap tahapannya. Pada tahap pertama, think (berpikir): siswa dituntut untuk menyelesaikan sebuah bacaan permasalahan dengan cara membaca dan menafsirkan makna dan masalah tersebut yang kemudian mengharuskan siswa membuat catatan kecil. Pada tahap kedua, talk (berbicara): siswa dituntut mengomunikasikan ide matematika secara lisan dengan cara mendiskusikan hasil catatan yang telah dibuat kepada satu kelompoknya untuk mengumpulkan informasi dan penarikan kesimpulan. Pada tahap ketiga, write (menulis): siswa dituntut untuk mengomunikasikan ide matematika secara tulisan untuk menyajikan jawaban yang telah didiskusikan. 
Komunikasi matematika memiliki peran penting dalam pembelajaran matematika, sebab melalui komunikasi matematika siswa dapat mengorganisasikan pemikiran matematika. Hal ini diperkuat oleh Walle (2008: 4), bahwa belajar berkomunikasi dalam matematika membantu perkembangan interaksi dan penungkapan ideide di dalam kelas karena siswa belajar dalam suasana yang aktif.

Lestari dan Yudhanegara (2015:83) mengemukakan bahwa indikator yang dapat digunakan untuk mengukur kemampuan komunikasi matematika siswa yaitu: 1) menghubungkan gambar, diagaram, atau benda nyata ke dalam ide matematika; 2) menjelaskan atau mendeskripsikan ide matematika menjadi gambar, grafik, tabel, atau benda nyata; 3) mengungkapkan peristiwa sehari-hari dalam bahasa matematika; 4) melakukan diskusi, mendengarkan, dan menulis tentang matematika; 5) membaca dan memahami presentasu matematika dalam bentuk tertulis; 6) membuat pertanyaan matematika yang sesuai dengan masalah; dan 7) membuat kesimpulan, mendefinisikan, atau menyusun argumen.

Penggunaan model pembelajaran adalah salah satu cara membuat proses pembelajaran menjadi lebih menarik dan bermakna. Pembelajaran yang menarik dan bermakna dalam hal ini adalah dengan menggunakan model pembelajaran TTW dan media bantu belajar seperti media Monomat (Monopoli Matematika).

Adanya media Monomat memfasilitasi siswa untuk menyelesaikan dan mengisi kolom Lembar Kerja Siswa (LKS) yang sudah disediakan untuk menuliskan jawaban hasil perolehan kartu soal sehingga siswa dapat mengasah kemampuan dalam menyampaikan ide-ide matematika secara tertulis. Media Monomat juga mengasah siswa untuk bisa saling berdiskusi dengan teman satu kelompok dan saling berintarksi mengomunikasikan gagasan matematika siswa. Melalui media Monomat ini, siswa merasa lebih tertarik karena pembelajaran tidak membosankan dan siswa bisa belajar sambal bermain. Hal tersebut senada dengan pendapat Pitadjeng (dalam Sutrisno dan Hidayah 2014:226) yang menyatakan bahwa belajar akan efektif jika dilakukan dalam suasana yang menyenangkan. Dalam hal ini, suasana menyenangkan diciptakan dari penggunaan media Monomat.

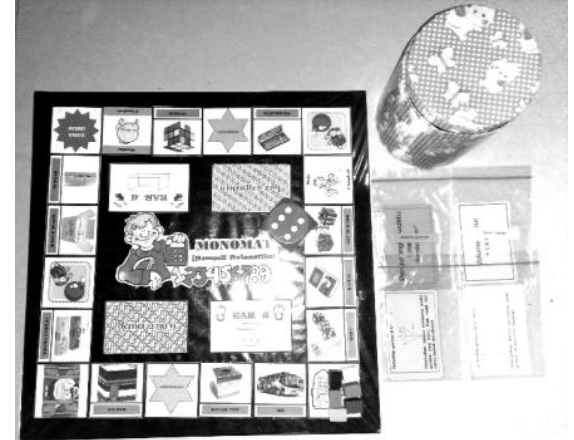

Gambar 1. Media Monomat

Adapun langkah-langkah pembelajaran dengan menggunakan model TTW berbantuan media Monomat adalah: 1) tahap think: Siswa membaca bacaan permasalahan yang dibagikan guru secara individu dan membuat catatan dari hasil memikirkan kemungkinan jawaban dari bacaan permasalalahan; 2) tahap talk: guru membagi kelompok yang terdiri dari 3-6 siswa, kemudian siswa mendiskusikan catatan masingmasing untuk menyelesaikan bacaan permasalahan, setelah itu siswa mendiskusikan LKS dengan memainkan media Monomat yang sebelumnya sudah guru bagikan; 3) tahap write: siswa bersama kelompok menggabungkan, menyusun, dan menuliskan ide yang didapat untuk menuliskan jawaban bacaan permasalahan dan LKS, setelah itu perwakilan anggota kelompok maju membacakan hasil diskusi, dan terakhir guru dan siswa menyimpulkan hasil diskusi.

Langkah-langkah dalam pembelajaran dikendalikan oleh guru, karena itu guru harus mempunyai keterampilan mengajar yang memadai agar mampu mengelolal pembelajaran dengan baik. Hal tersebut sejalan dengan Sanjaya (2013:33) bahwa keterampilan dasar mengajar bagi guru diperlukan agar guru dapat melaksanakan perannya dalam pengelolaan proses pembelajaran, sehingga pembelajaran dapat berjalan secara efektif dan efisien. Usman (2011:74) menyebutkan bahwa indikator keterampilan mengajar guru mencakup 8 indikator, diantaranya: 1) keterampilan membuka pelajaran; 2) keterampilan menjelaskan; 3) keterampilan bertanya; 4) keterampilan mengelola kelas; 5) keterampilan mengadakan variasi; 6) keterampilan membimbing diskusi kelompok; 7) keterampilan memberikan penguatan; dan 8) keterampilan menutup pelajaran.

Guru yang mempunyai keterampilan mengajar yang baik akan berdampak pada aktivitas belajar siswa yang juga baik dalam kemampuan komunikasi matematika. Daryanto dan Tasrial (2012:85) mendefinisikan bahwa aktivitas belajar (learning activities) dapat 
digunakan untuk mengajar dan mengetes pengetahuan, kemampuan dan kepercayaan kepada siswa. Aktivitas belajar siswa menurut Djaramah (2011:38) meliputi 8 aspek, namun yang dipakai dalam penelitian ini hanya mengambil 5 aspek yaitu: 1) mendengarkan; 2) menulis/mencatat; 3) membaca; 4) berpikir; dan 5) berbicara.

Berdasarkan uraian di atas, kemampuan komunikasi matematika siswa dapat ditingkatkan melalui model pembelajaran TTW karena akan mendorong siswa untuk bisa berpikir, berbicara, dan menuliskan suatu topik tertentu sehingga dapat mempengaruhi siswa mengembangkan ide atau gagasan matematikanya melalui lisan ataupun tulisan.

\section{METODE PENELITIAN}

Metode penelitian menjelaskan rancangan kegiatan, ruang lingkup atau objek, bahan dan alat utama, tempat, teknik pengumpulan data, definisi operasional variabel penelitian, dan teknik analisis data.

Penelitian ini merupakan penelitian tindakan kelas yang dilaksanakan di SD 1 Wergu Kulon Kudus. Subjek dari penelitian ini yaitu guru sebagai peneliti dan 29 siswa kelas V. Penelitian ini berlangsung selama 2 siklus yang setiap siklusnya terdiri dari 4 tahap yaitu perencanaan, pelaksanaan, observasi, dan refleksi. Variabel bebas dari penelitian ini adalah model pembelajaran Think Talk Write, sedangkan variabel bebasnya yaitu kemampuan komunikasi matematika siswa.

Teknik pengumpulan data menggunakan teknik tes, observasi, wawancara, dan dokumentasi. Guna mendapatkan data yang akurat, instrumen yang digunakan yaitu lembar soal tes kemampuan komunikasi matematika, lembar observasi keterampilan mengajar guru dan aktivitas belajar siswa, lembar wawancara, dan foto kegiatan pembelajaran. Sebelum soal tes diberikan kepada siswa, terlebih dahulu dilakukan uji validitas dan uji reliabilitas, kemudian hasil $r$ hitung dibandingkan dengan $r$ tabel sebesar 0.532. Teknik analisis data yang digunakan merupakan analisis data kuantitatif dan kualitatif. Data kuantitatif berupa nilai tes yang mengukur kemampuan komunikasi matematika siswa, sedangkan data kualitatif dalam penelitian ini diperoleh melalui lembar observasi keterampilan mengajar guru dan aktivitas belajar siswa selama proses pembelajaran matematika dengan menggunakan model Think Talk Write berbantuan media Monomat. Guna menganalisis dan mensintesiskan data kualitatif tersebut dilakukan dengan menggunakan teknik rating scale.
Indikator keberhasilan dalam penelitian ini adalah sebagai berikut.

1. Keterampilan guru dalam mengajar dengan menggunakan model TTW berbantuan media Monomat materi bangun datar dan bangun ruang meningkat dengan kriteria minimal baik dengan skor rata-rata $>2.5$.

2. Aktivitas belajar siswa dalam kemampuan komunikasi matematika siswa meningkat dengan menggunakan model TTW berbantuan media Monomat materi bangun datar dan bangun ruang dalam kriteria baik dnegan skor rata-rata $>2,5$.

3. Rata-rata kemampuan komunikasi matematika siswa kelas V SD 1 Wergu Kulon meningkat dengan menggunakan model TTW berbantuan media Monomat pada materi bangun datar dan bangun ruang mencapai nilai rata-rata 65 dengan ketuntasan klasikal minimal $75 \%$.

\section{HASIL DAN PEMBAHASAN}

Pada penelitian tindakan kelas ini, pembelajaran matematika yang dilakukan di kelas V SD 1 Wergu Kulon pada materi menyelesaikan masalah tentang tentang bangun datar dan bangun ruang sederhana melalui model Think Talk Write berbantuan media Monomat terdiri dari 3 tahap pembelajaran.

Tahap pertama yaitu think (berpikir). Langkah komunikasi matematika siswa pada tahap ini adalah mengungkapkan peristiwa sehari-hari dalam bahasa matematika. Tahap ini diawali dengan pembagian bacaan permasalahan pada setiap siswa, kemudian siswa diberikan waktu untuk berpikir menyelesaikan bacaan permasalahan tersebut dengan cara membuat catatan kecil tentang hal-hal yang diketahui. Media Monomat pada tahap ini belum digunakan.

Tahap kedua yaitu talk (berbicara). Langkah komunikasi matematika dalam tahap ini adalah melakukan diskusi dan mendengarkan tentang matematika. Tahap ini merupakan tahap lanjutan dari tahap berpikir. Pada tahap ini, catatan yang dibuat oleh siswa kemudian dibawa ke forum diskusi untuk dilakukan penyelesaian bacaan permasalahan secara bersama dan pengambilan keputusan jawaban mana yang akan dipakai. Selanjutnya adalah membaca dan memahami presentasi matematika secara tertulis dengan menggunakan media Monomat. Media Monomat dimainkan secara bergiliran sesuai urutan. Siswa/pemain pertama mengambil kartu soal sesuai dengan munculnya mata dadu. Kartu soal berisi permasalahan yang harus diselesaikan secara bersama dengan siswa lain. Kartu soal yang didapatkan kemudian dituliskan di kolom 
LKS yang telah disediakan. Pada tahap ini, siswa lebih mudah mengekspresikan ide-ide atau gagasan matematika secara lisan dengan menggunakan media Monomat.

Pengisian LKS meliputi indikator menghubungkan gambar menjadi ide matematika dan menjelaskan ide matematika menjadi sebuah gambar. Dari jawaban LKS yang telah dituliskan, siswa sudah bisa menyelesaikan permasalahan dari kartu soal media Monomat dengan baik. Hal tersebut dapat dibuktikan dari hasil pengisian jawaban LKS yang sudah memuat hal yang diketahui, ditanyakan, dan pembuktian. Langkah dan hasil pengisian LKS disajikan pada Gambar 2 dan Gambar 3.

Petunjuk:
1. Buatlah 2 buah bangun datar yang memiliki 4 sisi yang
sama panjang dengan ukuran yang berbeda
menggunakan alat dan bahan di samping, sertakan
ukuran, bagian, dan keterangan bangun yang kalian
gambarl

Gambar 2. Langkah pengisian LKS

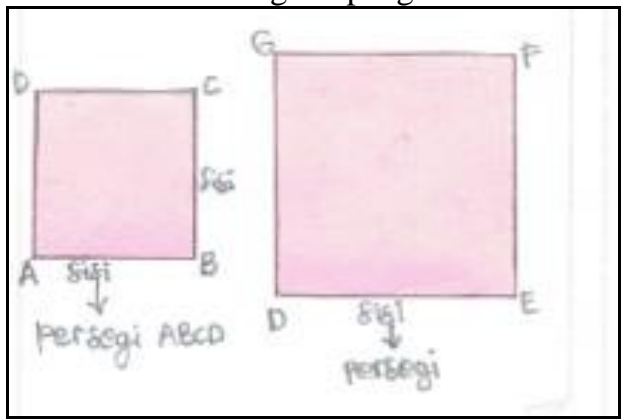

Gambar 3. Hasil indikator menjelaskan ide matematika menjadi gambar.

Tahap ketiga yaitu tahap write (menulis). Langkah komunikasi matematika pada ini yaitu menulis tentang matematika dan membuat kesimpulan. Bacaan permasalahan dan kartu soal dari media Monomat yang telah didiskusikan kemudian dituliskan hasil jawabannya di tempat yang telah disediakan oleh guru. Dari tahap ini, siswa sudah cukup baik dalam menuliskan jawaban permasalahan dan kartu soal dari media Monomat.

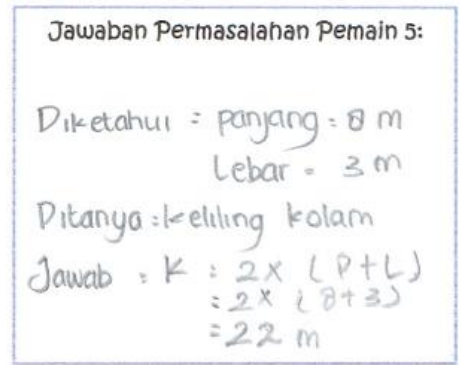

Gambar 4. Hasil Mengungkapkan ide matematika siklus I

Pengisian kartu soal dari media Monomat yang ditunjukkan oleh Gambar 4 masih kurang maksimal dalam mengungkapkan ide-ide matematika. Siswa belum menuliskan hal yang diketahui secara lengkap, misalnya diketahui panjang kolam renang $=8 \mathrm{~m}$, dan lebar kolam renang $3 \mathrm{~m}$. Ditanyakan juga belum dituliskan secara lengkap, seharusnya dituliskan apakah keliling kolam lebih dari $20 \mathrm{~m}$ sesuai dengan permasalahan pada kartu soal. Pembuktian jawaban sudah benar namun belum disertai dengan penulisan kesimpulan.

Kegiatan pembelajaran dilanjutkan dengan presentasi tiap kelompok untuk membacakan hasil diskusi masing-masing dan untuk menanggapi hasil diskusi. Kegiatan pembelajaran diakhiri dengan penarikan kesimpulan yang dilakukan oleh guru bersama siswa dalam kegiatan pembelajaran pada hari itu. Guru melakukan tanya jawab tentang apa yang belum dan sudah dipahami oleh siswa. Sebelumnya di tiap akhir siklus dilakukan evaluasi untuk mengukur seberapa besar kemampuan komunikasi matematika siswa yang telah dicapai selama pembelajaran matematika dengan menggunakan model Think Talk Write berbantuan media Monomat.

Hasil rata-rata tes kemampuan komunikasi matematika siswa pada siklus I memperoleh nilai rata-rata sebesar 66,20 dengan kriteria baik dan ketuntasan klasikal sebesar $62,06 \%$. Nilai rata-rata tiap indikator kemampuan komunikasi matematika adalah sebagai berikut. Sebanyak 77,24 diperoleh dari nilai rata-rata indikator menghubungkan gambar menjadi ide matematika. Indikator menjelaskan ide matematika menjadi sebuah gambar memperoleh nilai rata-rata kelas sebesar 74,3. Sebesar 70,34 diperoleh dari nilai rata-rata kelas dari indikator mengungkapkan peristiwa seharihari dalam bahasa matematika. Indikator melakukan diskusi, mendengarkan, dan menulis matematika memperoleh nilai rata-rata kelas sebesar 66,55. Sebesar 44,83 diperoleh dari indikator membaca dan memahami presentasi matematika dalam bentuk tertulis. Indikator membuat pertanyaan matematika yang sesuai dengan permasalahan dan indikator membuat kesimpulan memperoleh nilai rata-rata kelas sebesar 62,07 dan 63,45 secara berturut-turut.

Sementara itu, perolehan hasil observasi keterampilan guru memperoleh nilai rata-rata sebesar 2,93 dengan kategori berhasil dan kualifikasi "B". Hasil aktivitas belajar siswa memperoleh nilai rata-rata sebesar 2,72 dengan kategori berhasil dan kualifikasi "B".

Sesuai dengan penjelasan tersebut, dapat diketahui bahwa nilai rata-rata kemampuan komunikasi matematika siswa sudah mencapai $\geq$ 65 , namun belum mencapai ketuntasan klasikal 
seperti indikator keberhasilan yang telah ditetapkan. Hasil keterampilan mengajar guru yang dalam hal ini adalah peneliti dalam mengelola pembelajaran matematika dengan menggunakan model Think Talk Write dan aktivitas belajar siswa dengan berbantuan media Monomat sudah mencapai indikator keberhasilan. Sudah tercapainya indikator keberhasilan bukan berarti sudah baik dan tidak ada masalah, namun terdapat kekurangan selama pelaksanaan kegiatan pembelajaran. Berikut adalah kekurangan hasil keterampilan mengajar guru, aktivitas belajar siswa yang diperoleh dari hasil observasi pada siklus I.

1. Pada tahap think (berpikir) yang berkaitan dengan aktivitas berpikir, banyak siswa yang kebingungan dan belum paham dalam menyelesaikan bacaan permasalahan.

2. Pada tahap talk (berbicara) yang berkaitan dengan aktivitas berbicara dan mendengarkan, kurang ada kerjasama dalam kegiatan diskusi kelompok dan penggunaan media Monomat yang dikuasai oleh salah satu atau dua orang siswa saja.

3. Pada tahap write (menulis) yang berkaitan dengan aktivitas menulis, kesempatan siswa menyampaikan pendapat belum maksimal dan merata. Siswa juga tidak menuliskan sendiri hasil jawaban kartu soal media Monomat.

Kegiatan pembelajaran pada siklus I dengan menggunakan model Think Talk Write berbantuan media Monomat pada materi menyelesaikan permasalahan yang berkaitan dengan bangun datar dan bangun ruang sederhana sudah cukup memberikan hasil yang baik. Cukup baik perlu ditingkankan lagi karena masih terdapat beberapa kekurangan selama pelaksanaan dan harus mendapatkan perbaikan untuk siklus II. Berikut ini adalah perbaikan yang dilakukan peneliti untuk mengatasi kekurangan pada siklus I.

1. Pada tahap think, peneliti harus memberikan penjelasan dan arahan yang jelas dalam menyelesaikan bacaan permasalahan.

2. Pada tahap talk, peneliti harus memberikan bimbingan kelompok secara merata dan juga guru harus memotivasi siswa untuk bisa aktif berpartisipasi dalam kegiatan diskusi kelompok seperti memainkan dan menjawab kartu soal yang ada pada media Monomat.

3. Pada tahap write, peneliti harus mengalokasi waktu pembelajaran secara maksimal agar setiap kelompok ada kesempatan untuk menyampaikan hasil diskusinya dan guru juga harus mendampingi dan memeriksa jawaban tiap individu dalam menuliskan jawaban kartu soal media Monomat.

Berikut ini adalah uraian pembelajaran dengan menggunakan model Think Talk Write berbantuan media Monomat pada materi menyelesaikan bangun datar dan bangun ruang pada siklus II.

Tahap pertama yaitu think. Pada tahap ini siswa sudah bisa menyelesaikan bacaan permasalahan dengan baik. Catatan yang dibuat oleh tiap siswa sudah cukup lengkap.

Tahap kedua yaitu talk. Pada tahap ini siswa berdiskusi dengan baik dalam kegiatan pengisian LKS dan memainkan media Monomat guna menjawab beberapa kartu soal. Setiap kelompok sudah aktif berpartisipasi dalam menyampaikan ide-ide dan gagasan matematika pada anggota kelompok masing-masing. Langkah pengerjaan LKS sudah diperhatikan dan hasil pengerjaannya sudah tepat. Keduanya dapat dilihat pada gambar 5 dan Gambar 6.

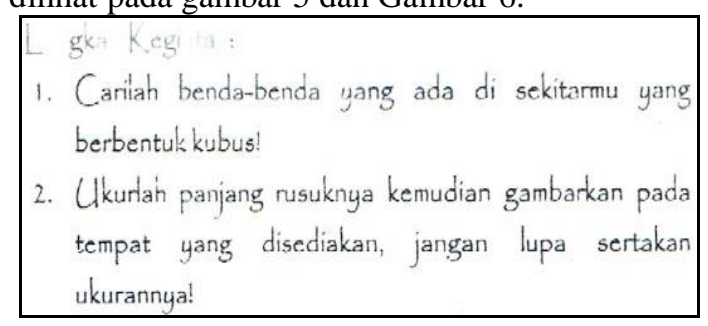

Gambar 5. Langkah pengisian LKS

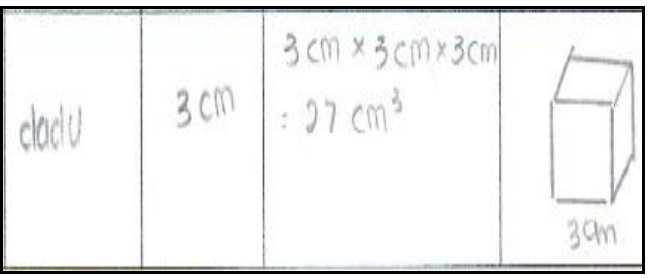

Gambar 6. Hasil indikator menjelaskan ide matematika menjadi gambar pada LKS

Tahap ketiga yaitu write. Pada tahap ini siswa menuliskan hasil pengisian LKS dan hasil jawaban kartu soal media Monomat. Siswa sudah menuliskan jawaban LKS dengan lengkap. Jawaban kartu soal media Monomat juga dituliskan dengan benar. Dilengkapi dengan hal yang diketahui, ditanyakan, pembuktian, dan kesimpulan sudah dituliskan dengan baik dan benar. 


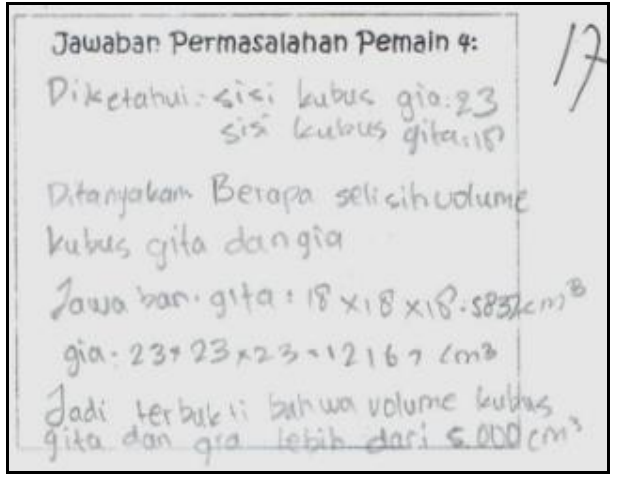

Gambar 7. Hasil Mengungkapkan ide matematika menjadi gambar pada siklus II

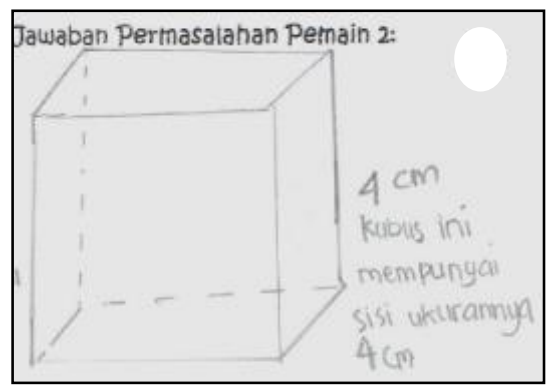

Gambar 8. Hasil Mengungkapkan ide matematika menjadi gambar pada siklus II

Hasil rata-rata tes kemampuan komunikasi matematika siswa pada siklus II memperoleh nilai rata-rata sebesar 79,59 dengan kriteria baik dan mencapai ketuntasan klasikal sebesar 79,31\%. Nilai rata-rata tiap indikator kemampuan komunikasi matematika adalah sebagai berikut. Sebanyak 84,83 diperoleh dari nilai rata-rata indikator menghubungkan gambar menjadi ide matematika. Indikator menjelaskan ide matematika menjadi sebuah gambar memperoleh nilai rata-rata kelas sebesar 86,72. Sebesar 78,79 diperoleh dari nilai rata-rata kelas dari indikator mengungkapkan peristiwa seharihari dalam bahasa matematika. Indikator melakukan diskusi, mendengarkan, dan menulis matematika memperoleh nilai rata-rata kelas sebesar 80,69. Sebesar 70 diperoleh dari indikator membaca dan memahami presentasi matematika dalam bentuk tertulis. Indikator membuat pertanyaan matematika yang sesuai dengan permasalahan dan indikator membuat kesimpulan memperoleh nilai rata-rata kelas sebesar 74,14 dan 70,34 secara berturut-turut. Dari hasil tersebut dapat dikatakan bahwa pembelajaran matematika pada siklus II telah mencapaik indikator yang telah ditetapkan.

Seorang guru harus memiliki keterampilan yang baik untuk dapat dengan mudah menguasai kelas dalam melaksanakan pembelajaran dan mencapai tujuan pembelajaran yang diinginkan. Uno (2016:130) menjelaskan bahwa guru yang memiliki keterampilan mengajar, dapat mengelola pembelajaran dengan baik Pernyataan tersebut sependapat dengan Sanjaya (2013:33) yang menyatakan bahwa keterampilan dasar mengajar seorang guru diperlukan agar guru dapat melaksanakan perannya dalam pengelolaan proses pembelajaran sehingga pembelajaran dapat berjalan dengan efektif dan efisien.

Mengajar adalah tugas pokok seorang guru yang membutuhkan keterampilan. Sebagaimana yang telah dijelaskan oleh Hamdayama (2016:49) bahwa seorang guru yang baik setidaknya perlu memiliki delapan keterampilan dasar dalam mengajar sehingga pembelajaran dapat menciptakan keberhasilan. Efektif atau tidaknya pembelajaran ditentukan oleh keterampilan dasar yang dimiliki oleh guru, jadi guru harus bisa membawa siswanya untuk dapat mencapai tujuan pembelajaran yang ingin dicapai.

Hal yang dapat dilakukan guru agar mencapai keefektifan dalam pembelajaran adalah adalah memilih serta menggunakan model pembelajaran. Hal ini juga harus disesuaikan dengan materi yang diajarkan. Model pembelajaran yang sesuai untuk menyampaikan materi bangun datar dan bangun ruang guna meningkatkan kemampuan komunikasi matematika siswa dan aktivitas belajar yang baik bagi kelas V SD 1 Wergu Kulon yaitu model Think Talk Write. Model TTW dipilih karena menjadikan siswa untuk bisa berpikir, berbicara, dan menuliskan suatu topik tertentu sehingga dapat mempengaruhi siswa mengembangkan ide atau gagasan matematikanya dengan media pembelajaran yang menarik dan menyenangkan dengan media Monomat.

Model TTW berbantuan media Monomat dalam pembelajaran matematika ini untuk meningkatkan kemampuan komunikasi matematika siswa melalui model pada materi bangun datar dan bangun ruang. Hasilnya yaitu kemampuan komunikasi matematika siswa semakin meningkat di tiap siklusnya. Tingkat kemampuan komunikasi matematika siswa kelas V SD 1 Wergu Kulon pada materi bangun datar dan bangun ruang ditentukan oleh hasil evaluasi pada siklus I dan II dengan menggunakan tes uraian (subjektif). Bentuk tes uraian dipilih agar dapat mengetahui secara rinci hasil jawaban yang dikerjakan siswa dengan berbagai cara atau pendapat yang berbeda dari masing-masing siswa. Hal tersebut senada dengan pendapat yang dikemukakan oleh Arifin (2013:125) bahwa tes uraian menuntut siswa untuk menguraikan, mengorganisasikan dan menyatakan jawaban dengan kata-katanya sendiri dalam bentuk, 
teknik, dan gaya yang berbeda satu dengan yang lainnya.

Dalam pelaksanaan pembelajaran TTW menggunakan media Monomat dibentuk beberapa kelompok diskusi. Setiap anggota kelompok nampak senang dan antusias dalam belajar. Hal tersebut sejalan dengan pendapat Khoirunnisa dan Susanto (2015:70) yang mengatakan bahwa dengan menggunakan media permainan dapat meningkatkan energy dan keterlibatan siswa yang juga berguna untuk membentuk poin-poin dramatis yang jarang dilupakan oleh siswa. Selain itu, menurut Selain itu, penelitian Ulya dan Rahayu (2017) juga memberikan hasil bahwa bahwa melalui pembelajaran berbantuan permainan dapat meningkatkan sikap siswa terhadap matematika sehingga aktivitas belajar siswa juga meningkat.

\section{SIMPULAN}

Berdasarkan hasil penelitian yang telah dilakukasn, dapat disimpulkan bahwa pembelajaran matematika di kelas V SD 1 Wergu Kulon dengan menggunakan model Think Talk Write berbantuan media Monomat terbukti dapat meningkatkan kemampuan komunikasi matematika siswa.

Saran dalam penelitian ini yaitu guru hendaknya memberikan alokasi waktu yang jelas pada saat pemberian tugas supaya siswa dapat dengan mudah mengatur waktu pada saat mengerjakan dan guru juga perlu memantau jalannya diskusi antar kelompok sehingga dapat dengan mudah mengetahui dan menegur siswa yang tidak berpartisipasi. Bagi siswa, hendaknya dapat lebih aktif, partisipatif, dan responsif dalam mengikuti pembelajaran yang telah diajarkan oleh guru sehingga memperoleh hasil maksimal dan berkualitas, siswa harus meningkatkan rasa percaya diri dan tidak takut salah ketika menyampaikan pendapat, diskusi, dan hasil pemikirannya. Bagi sekolah, penelitian tindakan ini hendaknya dapat dijadikan bahan perubahan dan pertimbangan untuk memfasilitasi siswa dalam belajar agar mutu sekolah dapat meningkat.

\section{UCAPAN TERIMAKASIH}

Penulis mengucapkan terimakasih kepada segenap tim Pengelola Jurnal Anargya yang telah memberikan kesempatan kepada penulis untuk mempublikasikan karya ilmiahnya.

\section{DAFTAR PUSTAKA}

Arifin, Zainal. 2013. Evaluasi Pembelajaran. Bandung: Remaja Rosdakarya

BSNP. 2006. Peraturan Menteri Pendidikan Nasional Republik Indonesia No 22
Tahun 2006 tentang Standar Isi untuk Satuan Pendidikan Dasar dan Menengah. Jakarta: Badan Standar Nasional Pendidikan.

Daryanto dan Tasrial. 2012. Konsep Pembelajaran Kreatif. Yogyakarta: Gava Media.

Djamarah, Syaiful Bahri. 2011. Psikologi Belajar Edisi II. Jakarta: PT. Rineka Cipta.

Hamdayama, Jumanta. 2014. Model dan Metode Pembelajaran Kreatif dan Berkarakter. Bogor: Ghalia Indonesia.

Khoirunnisa dan Susanto. 2015. Pembelajaran Kooperatif Tipe Teams-GamesTournament Model Monopoli Berbasis Karakter untuk Meningkatkan Prestasi Belajar Fisika. Unnes Physics Education Journal. 4 (2): 69-74.

Lestari, Karunia Eka dan Mokhammad Ridwan Yudhanegara. 2015. Penelitian Pendidikan Matematika. Bandung: PT. Refika Aditama.

Sanjaya, Wina. 2013. Strategi Pembelajaran Berorientasi Standar Proses Pendidikan. Jakarta: Kencana Prenadamedia Group.

Sutrisno, Hidayah. 2014. Peningkatan Hasil Belajar Siswa Pada Materi Operasi Hitung Bilangan Berpangkat Dengan Media Molikur-13 di Kelas VI SD 10 Malinau Kota. J-TEQIP. 1 (2): 226-238.

Ulya, H., dan Rahayu, R. 2017. Increasing Primary School Students' Attitude Toward Mathematics Through The Implementation Of Treffinger Learning Using Dakon Game. International Conference On Education, 1 (01): 1-7.

Uno, Hamzah B. 2016. Orientasi Baru Dalam Psikologi Pembelajaran. Jakarta: PT. Bumi Aksara.

Usman, Moh. Uzer. 2011. Menjadi Guru Profesional. Bandung: PT. Remaja Rosdakarya

Walle, John A Van. 2008. Matematika Pengembangan Pembelajaran. Jakarta: Erlangga. 